\title{
Somatic mutations of STK11 gene in human papillomavirus positive and negative penile cancer
}

\author{
Clorinda Annunziata ${ }^{1}$, Luigi Buonaguro', Simona Losito², Franco M Buonaguro ${ }^{1}$ and Maria Lina Tornesello ${ }^{*}$
}

\begin{abstract}
Background: Human papillomavirus (HPV) infection accounts for about $40-50 \%$ of all cases of penile carcinoma suggesting that other factors, including host genetic status, are involved in neoplastic transformation. In this perspective, STK11 gene, which has been found frequently mutated in HPV-related cervical carcinoma, has been analyzed in HPV-positive and HPV-negative invasive penile cancers to establish its mutational status and the possible correlation of HPV infection with specific genetic alterations.
\end{abstract}

Methods: Genomic DNAs extracted from 26 cases of penile squamous cell carcinoma were analyzed for genetic alterations in the exons 1 to 9 of STK11 gene by quantitative real-time PCR. Ratios of potentially deleted and non-deleted exons were indicative of specific loss of STK11 coding regions. DNA samples of 5 cancer cases were subjected to standard PCR amplification of STK11 exons 1 to 9 and analyzed for somatic mutations by direct nucleotide sequencing analysis.

Results: Heterozygous deletions of STK11 exon 1 and 2 were identified in 2 out of 14 HPV-positive (14.3\%) and 1 out of 12 HPV-negative cases (8.3\%). Complete nucleotide sequencing analysis of exons 1 to 9 showed a single nucleotide change upstream the exon 2 coding region in 1 out of 5 penile carcinoma samples.

Conclusions: The present results suggest that single nucleotide mutations and/or deletions of STK11 gene are rare events in penile cancer. Moreover, no significant association was observed between STK11 alterations and HPV infection in these tumors.

Keywords: HPV, STK11, Somatic mutations, Penile cancer

\section{Background}

Penile cancer is a rare malignancy in Western Europe and the United States with age-standardized incidence rates (ASR) of 0.1-1.5 per 100,000 men. In Africa, Asia and South America, however, the estimate ASRs are significantly higher with peaks of 2.8 and 3.7 per 100,000 men, in Uganda and Brazil, respectively [1].

The most common histological type of penile carcinoma is the squamous cell carcinoma (95\%) which comprises several subtypes such as usual squamous cell carcinoma (48-65\%), basaloid (4-10\%), warty $(7-10 \%)$, verrucous (3-8\%), papillary (5-15\%) and mixed carcinoma (9-10\%)

\footnotetext{
* Correspondence: m.tornesello@istitutotumori.na.it

'Molecular Biology and Viral Oncology, National Cancer Institute "Fond. Pascale", Cappella Cangiani, 80131, Naples, Italy

Full list of author information is available at the end of the article
}

[2]. Although the etiology of penile cancer is not yet fully understood several risk factors, such as poor hygiene and phimosis, lack of circumcision in childhood and history of smoking, have been shown to increase the risk to develop this malignancy [3-6]. Human papillomaviruses (HPV) have been associated with approximately $47 \%$ of invasive penile carcinoma cases with HPV16 and HPV18 as the most common viral genotypes accounting for $60.23 \%$ and $13.35 \%$, respectively, of the HPV attributable cases [7]. Higher rates of HPV positivity have been found in wartybasaloid (82\%), basaloid (76\%), and warty carcinomas (39\%). This observation was indicative of a strong association between the basaloid cell type and presence of HPV [8].

Several studies have reported genetic alterations in tumor suppressor genes and oncogenes, in both HPV-positive and

\section{Biomed Central}

(c) 2013 Annunziata et al.; licensee BioMed Central Ltd. This is an Open Access article distributed under the terms of the Creative Commons Attribution License (http://creativecommons.org/licenses/by/2.0), which permits unrestricted use, distribution, and reproduction in any medium, provided the original work is properly cited. 
HPV-negative penile cancers, which may have a critical role in tumor carcinogenesis $[9,10]$. STK11 is a $23 \mathrm{~kb}$ tumor suppressor gene, mapped to chromosome 19p13.3, which encodes for the serine/threonine kinase 11 (STK11) also known as liver kinase B1 (LKB1) or renal carcinoma antigen NY-REN-19 [11,12]. The STK11 gene is widely expressed in embryonic and adult tissues and the encoded STK11 kinase is an essential regulator of chromatin remodeling, cell cycle arrest, p53-dependent apoptosis, Wnt signaling, cell polarity and energy metabolism [13-15]. Germ-line mutations of the STK11 gene are associated with Peutz-Jeghers syndrome (PJ) $[11,12]$, an autosomal dominant disorder characterized by hamartomatous polyps of the gastrointestinal tract and by a considerably increased risk of cancer in gastrointestinal tract, pancreas, breast, lung, uterus, cervix, ovary and testis [16-18]. PJ patients are at increased risk to develop cancer particularly at body sites with higher levels of STK11 enzyme in the normal tissue [19].

Somatic mutations of STK11gene have been frequently found in several sporadic tumors, including HPV-related cervical cancer [20-25]. No studies have been performed on STK11 mutational status in penile carcinoma.

The aim of the present study was to analyze genetic alterations and single nucleotide mutations in exons 1 to 9 of STK11 gene in HPV-positive and HPV-negative penile cancers to possibly establish a relationship between HPV infection and genetic alterations involved in cancer progression.

\section{Methods}

\section{Samples and DNA isolation}

This study included DNA samples extracted from liquid-nitrogen frozen specimen of penile squamous cell carcinoma $(n=6)$ from Black Ugandan patients and paraffin-embedded penile squamous cell carcinoma $(\mathrm{n}=$ 20) from Caucasian Italian patients. These samples were previously characterized in terms of histology, DNA quality, HPV genotypes, HPV16 variants and viral integration status $[9,26]$. The study protocol was approved by the ethical review board of the involved Institution. Genomic DNA was extracted from frozen biopsies as well as from thin sections of fixed and embedded tissues according to published procedures $[27,28]$. In particular two $10 \mu \mathrm{m}$ sections of each biopsy were extracted twice with $1 \mathrm{ml}$ of xylenes, for paraffin removal, and twice with $500 \mu \mathrm{l}$ of $100 \%$ ethanol, for organic solvents removal. Both xylenes-treated and fresh tissue samples were digested with Proteinase $\mathrm{K}\left(150 \mu \mathrm{g}\right.$ per $\mathrm{ml}$ at $60^{\circ} \mathrm{C}$ for $30 \mathrm{~min})$ in $100-500 \mu \mathrm{l}$ lysis buffer $(10 \mathrm{mM}$ Tris- $\mathrm{HCl}$ pH 7.6, 5 mM EDTA, $150 \mathrm{mM} \mathrm{NaCl}, 1 \%$ SDS), followed by DNA purification by phenol and phenol-chloroformisoamyl alcohol (25:24:1) extraction and ethanol precipitation in $0.3 \mathrm{M}$ sodium acetate $(\mathrm{pH} 4.6)$. Genomic DNA was also extracted from PC23, HeLa and $\mathrm{SiHa}$ cell lines to be used as positive and negative control, respectively, in the PCR and real time PCR.

\section{Quantitative real-time PCR}

Exons 1 to 9 of STK11 gene were independently amplified by real time polymerase chain reaction (PCR) using primer sequences listed in Table 1. The nine primer pairs have been designed with Beacon Designer 7.9 (Bio Rad Laboratories, Inc). All STK11 exons were amplified in a total volume of $25 \mu \mathrm{l}$ containing iQ SYBR Green Supermix containing $50 \mathrm{mM} \mathrm{KCl}, 20 \mathrm{mM}$ Tris $-\mathrm{HCl}$, $\mathrm{pH} 8.4,0.2 \mathrm{mM}$ of each $\mathrm{dNTP}$ and 25 units $/ \mathrm{ml}$ iTaq DNA polymerase, $3 \mathrm{mM} \mathrm{MgCl} 2,10 \mathrm{nM}$ SYBR Green I (Bio-Rad Laboratories, Inc), $3 \mu \mathrm{mol} / \mathrm{L}$ of each primer, and $100 \mathrm{ng}-500 \mathrm{ng}$ of genomic DNA. All experiments were performed on the CFX96 Real Time System

Table 1 Primer sequences used for PCR, nucleotide sequence analysis and Real-time PCR amplification of STK11 exons 1 to 9

\begin{tabular}{|c|c|c|c|c|}
\hline Region & Forward $\left(5^{\prime}-3^{\prime}\right)$ & Reverse $\left(5^{\prime}-3^{\prime}\right)$ & Product length & $\begin{array}{l}\text { Annealing } \\
\text { temperature }\left({ }^{\circ} \mathrm{C}\right)\end{array}$ \\
\hline STK11 exon 1 & ACAATCGTTTCTGTTGGAAG & TCCTTGTGTTCCGACTTC & $113 \mathrm{bp}$ & 55 \\
\hline STK11 exon 2 & CTCTAGGGAAGGGAGGAG & TITCTGCTTCTCTTCGTTG & $201 \mathrm{bp}$ & 61 \\
\hline STK11 exon 3 & TGAGCTGTGTGTCCTTAG & CACTGGGAAACGCTTCTC & $102 \mathrm{bp}$ & 60 \\
\hline STK11 exon 4 & CCCGCAGGTACTTCTGTC & GTGGTGAGCAGCAGGTTC & $100 \mathrm{bp}$ & 61 \\
\hline STK11 exon 5 & CCTGAGGGCTGCACGGCACC & GGGGCGGGGCACTTACAGG & $180 \mathrm{bp}$ & 69 \\
\hline STK11 exon 6 & TCGAAATGAAGCTACAACATC & TTTCAGCAGGTCAGAGAG & $138 \mathrm{bp}$ & 61 \\
\hline STK11 exon 7 & TTCTCCTCAGGGATGCTTG & CACCTGTGCTGCCGGATC & $71 \mathrm{bp}$ & 60 \\
\hline STK11 exon 8 & ATGACTGTGGTGCCGTAC & CCGTGAAGTCCTGAGTGTAG & $100 \mathrm{bp}$ & 61 \\
\hline STK11 exon 9 & CAGGACAGGTCCCAGAAGAG & CCAGCCTCACTGCTGCTT & $203 \mathrm{bp}$ & 67 \\
\hline
\end{tabular}


(Bio-rad Laboratories, Inc). The specificity of amplification was confirmed applying dissociation analysis starting at $65^{\circ} \mathrm{C}$.

A 5-log dilution series of genomic DNA, extracted from the cell line PC23 [29], were amplified in each experiment for the construction of an absolute standard curve. This curve was used to determine the copy number of exon 1(test) and exon 7 (reference) of STK11 gene in the unknown samples. All PCR reactions were set up in duplicate.

Deletions of STK11 regions were verified by calculating the ratios $(R)$ of potentially deleted and non-deleted exons. Values of $\mathrm{R}$ between 0 and 0.3 and between 0.4 and 0.7 are assumed to be indicative of homozygous or heterozygous deletions, respectively; values of $\mathrm{R}$ between 0.8 and 1.2 indicate no changes of the copy number in the two exons.

\section{Mutation analysis of STK11 gene}

Exons 1 to 9 of STK11 gene were independently amplified by polymerase chain reaction (PCR). All primer sets, described in Table 1, were used to perform standard PCR reactions in $50 \mu \mathrm{l}$ reaction mixture containing 100
$500 \mathrm{ng}$ of target DNA, Hot Master buffer containing $2.5 \mathrm{mM} \mathrm{MgCl}, 20 \mathrm{pmol}$ of each primer, $200 \mu \mathrm{M}$ of dNTPs mix and 1.25 units of thermostable Taq DNA polymerase (5-Prime GmbH, Hamburg, DE). DNA was amplified in a Perkin-Elmer GenAmp PCR System 9700 thermal cycler with the following steps: an initial $2 \mathrm{~min}$ denaturation at $94^{\circ} \mathrm{C}$, followed by 36 cycles of $30 \mathrm{~s}$ at $94^{\circ} \mathrm{C}$, $30 \mathrm{~s}$ at the annealing temperature specified in Table. 1, $72^{\circ} \mathrm{C}$ for $30 \mathrm{~s}$, and a final elongation at $72^{\circ} \mathrm{C}$ for $5 \mathrm{~min}$. A reaction mixture without template DNA was included in each PCR run, as negative control. All products were analyzed by electrophoresis on $7 \%$ plyacrylamide gels to verify the specificity of the PCR product. Amplimers of STK11 exons 1-9 from 5 samples were subjected to automated direct nucleotide sequence analysis at Primm Laboratories (Milan, IT) using the same primers used for PCR amplification. STK11 mutations were sought by comparison analysis with the NG_007460.1 reference sequence present in the GenBank.

\section{Results}

Fourteen HPV-positive (53.9\%) and twelve HPV-negative (46.2\%) penile squamous cell carcinoma samples were

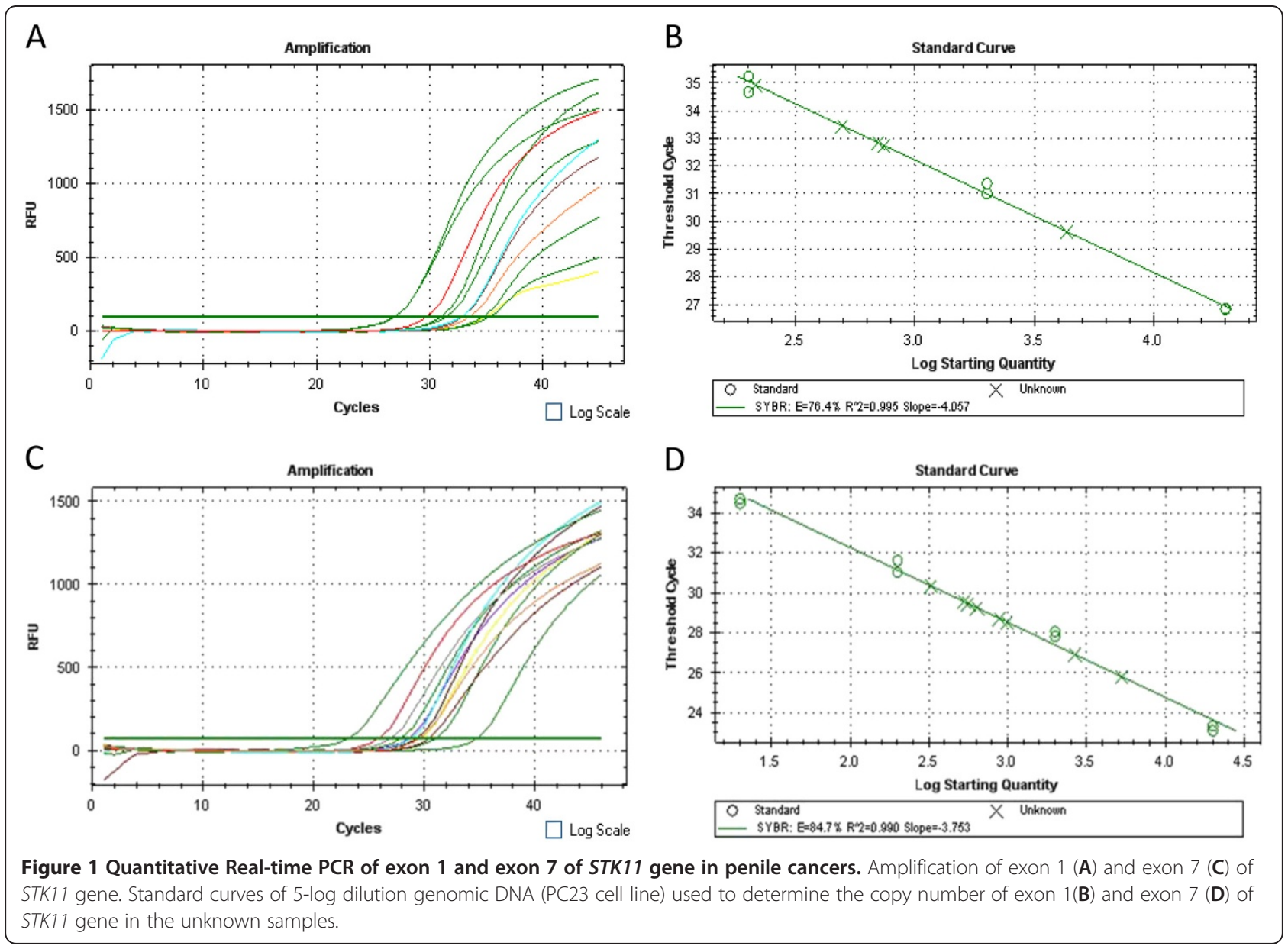


Table 2 List of penile cancer samples analysed for exon's deletions

\begin{tabular}{|c|c|c|c|c|c|c|}
\hline Sample & HPV & Exon 1 copy number & Exon 7 copy number & Exon $1 /$ Exon 7 ratio & Change of exon 1 copy number & Origin \\
\hline PC04 & HPV16 & $3.0 \times 10^{4}$ & $3.1 \times 10^{4}$ & 1 & no change & Uganda \\
\hline PC07 & HPV16 & $3.6 \times 10^{4}$ & $3.5 \times 10^{4}$ & 1 & no change & Uganda \\
\hline PC08 & HPV16 & $2.1 \times 10^{3}$ & $2.2 \times 10^{3}$ & 1 & no change & Uganda \\
\hline PC15 & HPV16 & $4.0 \times 10^{4}$ & $4.2 \times 10^{4}$ & 1 & no change & Uganda \\
\hline PC17 & HPV16 & $2.8 \times 10^{3}$ & $2.7 \times 10^{3}$ & 1 & no change & Uganda \\
\hline PC23 & HPV16 & $4.0 \times 10^{3}$ & $3.8 \times 10^{3}$ & 1.1 & no change & Uganda \\
\hline PC30 & HPV16 & 480 & 457 & 1.1 & no change & Italy \\
\hline PC31 & Negative & 648 & 651 & 1 & no change & Italy \\
\hline PC32 & HPV16 & 787 & 840 & 0.9 & no change & Italy \\
\hline PC33 & Negative & 637 & 765 & 0.8 & no change & Italy \\
\hline PC34 & Negative & 838 & 943 & 0.9 & no change & Italy \\
\hline PC35 & HPV 18 & 487 & 847 & 0.5 & heterozygous deletion & Italy \\
\hline PC36 & HPV16 & 950 & 975 & 1 & no change & Italy \\
\hline PC37 & HPV16 & 655 & 645 & 1 & no change & Italy \\
\hline PC38 & HPV16 & 780 & 795 & 1 & no change & Italy \\
\hline PC79 & HPV16 & 501 & 495 & 1 & no change & Italy \\
\hline PC80 & Negative & 457 & 432 & 1.1 & no change & Italy \\
\hline PC81 & Negative & 380 & 347 & 1.1 & no change & Italy \\
\hline PC82 & Negative & 468 & 310 & 1.4 & no change & Italy \\
\hline PC84 & Negative & 930 & 971 & 1 & no change & Italy \\
\hline PC85 & HPV56/54 & 172 & 316 & 0.5 & heterozygous deletion & Italy \\
\hline PC90 & Negative & 215 & 475 & 0.4 & heterozygous deletion & Italy \\
\hline PC91 & Negative & 697 & 846 & 0.8 & no change & Italy \\
\hline PC92 & Negative & 461 & 553 & 0.8 & no change & Italy \\
\hline PC93 & Negative & 738 & 643 & 1.1 & no change & Italy \\
\hline PC94 & Negative & 806 & 780 & 1 & no change & Italy \\
\hline
\end{tabular}

analyzed for genetic alterations by real-time PCR using specific primer sets designed to individually amplify exons 1 to 9 . While exons 3 to 9 were always amplified, exons 1 and 2 were not efficiently amplified in 3 out of $26(11.5 \%)$ samples. All 26 samples were subjected to a further quantitative real-time PCR using primer pairs specific for exon 1 (test) and for exon 7 (reference) to determine an absolute quantification of genomic equivalents of exon 1 and exon 7 in each sample. A 5-log dilution series of genomic DNA, extracted from the cell line PC23, was also amplified in the same reaction set to obtain an amplification standard curve (Figure 1). As expected, in 23 out of 26 samples the ratio of exon $1 /$ exon 7 copy number was $R \geq 0.8$, indicating no deletions in exon 1 . In three out of 26 cases the ratio of exon 1/exon 7 was $\mathrm{R} \approx 0.5$, indicating the presence of an heterozygous deletion in the test exon. In particular, STK11 deletions were identified in 2 out of $14 \mathrm{HPV}$ positive (14.3\%) and 1 out of 12 HPV-negative cases (8.3\%) (Table 2). All three STK11 deleted cases were of Italian origin.

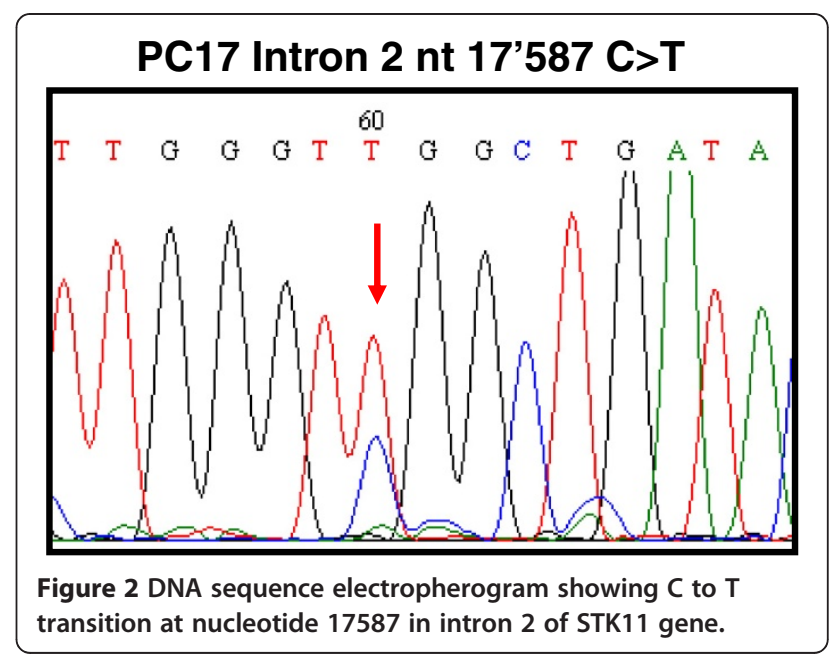


Moreover, nucleotide sequencing analysis of the whole coding region (exons 1 to 9) of STK11 gene was performed in 5 samples. A single nucleotide mutation, consisting of $\mathrm{C}$ to $\mathrm{T}$ transition at position 17587 in the intronic region 2 was detected in one case from Uganda out of $5(20 \%)$ total samples analyzed (Figure 2).

\section{Discussion}

The knowledge of genetic alterations in penile cancer is limited. In this study we investigated STK11 somatic mutations in both HPV-positive and HPV-negative penile squamous cell carcinoma cases, in order to verify a potential role of this tumor suppressor gene in penile tumorigenesis. The results obtained in our study showed that STK11 exon 1 and 2 are deleted in $11.5 \%$ of penile cancers. In particular, heterozygous deletions of STK11 exons 1 and 2 were observed in 14.3\% of HPV-positive and in $8.3 \%$ of HPV-negative tumors, indicating that HPV status has no effect on the genetic alteration of STK11 gene.

Genetic alterations of STK11gene have been identified in many sporadic cancers and derived cell lines, including HPV-related cervical carcinoma. In particular, Wingo et al. showed that up to $20 \%$ of cervical cancers harbored somatic mutations in STK11 coding regions, of which approximately one-half were single nucleotide substitutions or small deletions while the other half consisted of larger monoallelic or biallelic deletions [25]. Moreover they showed that the inactivation of this gene was associated with accelerated disease progression. Furthermore, an homozygous deletion of whole or of part of STK11gene was observed in $\mathrm{SiHa}$ and HeLa cell line $[24,25]$.

The nucleotide sequence analysis of exons 1 to 9 of STK11 in 5 penile carcinoma cases showed no somatic mutations in none of the 9 coding regions. A single nucleotide substitution was identified in the intron 2 of one cancer case, however it seems to have no effect on the expression of the protein. Somatic mutations, affecting conserved residues within the kinase domain or intron/exon junctions of STK11, were previously identified in 4 out of 6 cases $(66.7 \%)$ of cervical adenocarcinomas and 2 out of 10 cases (20\%) of squamous cell carcinomas, indicating that single nucleotide substitutions are frequent events in a specific histological subtype of cervical cancer [25].

Very few studies are available on somatic mutations of other genes in penile carcinoma. A recent report showed a dysregulation of phosphatidylinositol 3-kinase and Ras pathways through somatic alterations of the PIK3CA, HRAS and KRAS genes in 11 out of 28 (39\%) penile cancer samples, without any statistically significant difference between HPV-positive and HPV-negative cases [30].
Other studies analyzing genetic alterations in TP53 gene of penile carcinomas reported mutations in fractions varying from $8 \%$ to $33 \%$ of the cases [31-35]. Furthermore, most of reported alterations consist in single nucleotide mutations that cause amino acid substitution in the corresponding protein.

\section{Conclusions}

The present study has the limitation to analyze a modest sample size, but has the advantage to include cancer cases from high incidence (Uganda) and low incidence (Italy) geographic regions. The results obtained so far allow to conclude that single nucleotide mutations and/ or deletion of STK11 gene are rare events in penile carcinoma suggesting that STK11 genetic alterations do not have a relevant role in the pathogenesis of penile cancer.

Abbreviations

HPV: Human Papillomavirus; STK11: Serine/threonine kinase 11; LKB1: Liver kinase B1.

\section{Competing interests}

The authors report no competing of interests.

\section{Authors' contribution}

MLT and FMB were responsible for the overall planning and coordination of the study. LB contributed to the data analysis. SL carried out the histopathology evaluation of the cases. CA was responsible for specimen processing, DNA analysis and with MLT compiled and finalized the manuscript. All authors read and approved the final manuscript.

\section{Acknowledgements}

This work was supported by grants from the Ministero della Salute (Programma Integrato Oncologia RO4/2007) and from the ICSC-World Laboratory (project MCD-2/7).

\section{Author details}

${ }^{1}$ Molecular Biology and Viral Oncology, National Cancer Institute "Fond. Pascale", Cappella Cangiani, 80131, Naples, Italy. ${ }^{2}$ Department of Pathology, National Cancer Institute "Fond. Pascale", Naples, Italy.

Received: 13 December 2012 Accepted: 7 January 2013

Published: 10 January 2013

\section{References}

1. Curado MP, Edwards B, Shin HR, Ferlay J, Heanue M, Boyle P, Storm H: Cancer Incidence in Five Continents. Lyon: IARC Scientific Publications N 160; 2007.

2. Chaux A, Cubilla AL: Advances in the pathology of penile carcinomas. Hum Pathol 2012, 43:771-789.

3. Dillner J, Meijer CJ, von Krogh G, Horenblas S: Epidemiology of human papillomavirus infection. Scand J Urol Nephrol Suppl 2000, 205:194-200.

4. Daling JR, Madeleine MM, Johnson LG, Schwartz SM, Shera KA, Wurscher MA, Carter JJ, Porter PL, Galloway DA, McDougall JK, Krieger JN: Penile cancer: importance of circumcision, human papillomavirus and smoking in in situ and invasive disease. Int J Cancer 2005, 116:606-616.

5. Bleeker MC, Heideman DA, Snijders PJ, Horenblas S, Dillner J, Meijer CJ: History of circumcision, medical conditions, and sexual activity and risk of penile cancer. World J Urol 2009, 27:141-150.

6. Maden C, Sherman KJ, Beckmann AM, Hislop TG, Teh CZ, Ashley RL, Daling JR: Penile cancer: epidemiology, pathogenesis and prevention. J Natl Canc Inst 1993, 85:19-24.

7. Miralles-Guri C, Bruni L, Cubilla AL, Castellsague X, Bosch FX, De SS: Human papillomavirus prevalence and type distribution in penile carcinoma. J Clin Pathol 2009, 62:870-878.

8. Cubilla AL, Lloveras B, Alejo M, Clavero O, Chaux A, Kasamatsu E, Velazquez EF, Lezcano C, Monfulleda N, Tous S, Alemany L, Klaustermeier J, Munoz N, 
Quint W, De SS, Bosch FX: The basaloid cell is the best tissue marker for human papillomavirus in invasive penile squamous cell carcinoma: a study of 202 cases from Paraguay. Am J Surg Pathol 2010, 34:104-114.

9. Annunziata C, Buonaguro L, Buonaguro FM, Tornesello ML: Characterization of the human papillomavirus (HPV) integration sites into genital cancers. Molecular and genetic pathways in penile cancer. Pathol Oncol Res 2012, 18:803-808

10. Kayes $\mathrm{O}$, Ahmed HU, Arya M, Minhas S: Molecular and genetic pathways in penile cancer. Lancet Oncol 2007, 8:420-429.

11. Hemminki A, Avizienyte $E$, Roth $S$, Loukola A, Aaltonen $L A$, Jarvinen $H$, Dela CA: A serine/threonine kinase gene defective in Peutz-Jeghers syndrome. Duodecim 1998, 114:667-668.

12. Jenne DE, Reimann H, Nezu J, Friedel W, Loff S, Jeschke R, Muller O, Back W, Zimmer M: Peutz-Jeghers syndrome is caused by mutations in a novel serine threonine kinase. Nat Genet 1998, 18:38-43.

13. Alessi DR, Sakamoto K, Bayascas JR: LKB1-dependent signaling pathways. Annu Rev Biochem 2006, 75:137-163.

14. Marignani PA: LKB1, the multitasking tumour suppressor kinase. J Clin Pathol 2005, 58:15-19.

15. Ollila S, Makela TP: The tumor suppressor kinase LKB1: lessons from mouse models. J Mol Cell Biol 2011, 3:330-340.

16. Boardman LA, Thibodeau SN, Schaid DJ, Lindor NM, McDonnell SK, Burgart $\sqcup$, Ahlquist DA, Podratz KC, Pittelkow M, Hartmann LC: Increased risk for cancer in patients with the Peutz-Jeghers syndrome. Ann Intern Med 1998, 128:896-899.

17. Giardiello FM, Welsh SB, Hamilton SR, Offerhaus GJ, Gittelsohn AM, Booker SV, Krush AJ, Yardley JH, Luk GD: Increased risk of cancer in the PeutzJeghers syndrome. N Engl J Med 1987, 316:1511-1514.

18. Giardiello FM, Brensinger JD, Tersmette AC, Goodman SN, Petersen GM, Booker SV, Cruz-Correa M, Offerhaus JA: Very high risk of cancer in familial Peutz-Jeghers syndrome. Gastroenterology 2000, 119:1447-1453.

19. Conde E, Suarez-Gauthier A, Garcia-Garcia E, Lopez-Rios F, Lopez-Encuentra A, Garcia-Lujan R, Morente M, Sanchez-Verde L, Sanchez-Cespedes M: Specific pattern of LKB1 and phospho-acetyl-CoA carboxylase protein immunostaining in human normal tissues and lung carcinomas. Hum Pathol 2007, 38:1351-1360.

20. Kuragaki C, Enomoto T, Ueno Y, Sun H, Fujita M, Nakashima R, Ueda Y, Wada H, Murata Y, Toki T, Konishi I, Fujii S: Mutations in the STK11 gene characterize minimal deviation adenocarcinoma of the uterine cervix. Lab Invest 2003, 83:35-45.

21. Matsumoto S, Iwakawa R, Takahashi K, Kohno T, Nakanishi Y, Matsuno Y, Suzuki K, Nakamoto M, Shimizu E, Minna JD, Yokota J: Prevalence and specificity of LKB1 genetic alterations in lung cancers. Oncogene 2007, 26:5911-5918.

22. Kim CJ, Cho YG, Park JY, Kim TY, Lee JH, Kim HS, Lee JW, Song YH, Nam SW Lee SH, Yoo NJ, Lee JY, Park WS: Genetic analysis of the LKB1/STK11 gene in hepatocellular carcinomas. Eur J Cancer 2004, 40:136-141.

23. Kenanli E, Karaman E, Enver O, Ulutin T, Buyru N: Genetic alterations of the LKB1 gene in head and neck cancer. DNA Cell Biol 2010, 29:735-738.

24. McCabe MT, Powell DR, Zhou W, Vertino PM: Homozygous deletion of the STK11/LKB1 locus and the generation of novel fusion transcripts in cervical cancer cells. Canc Genet Cytogenet 2010, 197:130-141.

25. Wingo SN, Gallardo TD, Akbay EA, Liang MC, Contreras CM, Boren T, Shimamura T, Miller DS, Sharpless NE, Bardeesy N, Kwiatkowski DJ, Schorge JO, Wong KK, Castrillon DH: Somatic LKB1 mutations promote cervical cancer progression. PLoS One 2009, 4:e5137.

26. Tornesello ML, Duraturo ML, Losito S, Botti G, Pilotti S, Stefanon B, De PG, Gallo A, Buonaguro L, Buonaguro FM: Human papillomavirus genotypes and HPV16 variants in penile carcinoma. Int $J$ Cancer 2008, 122:132-137.

27. Fredricks DN, Relman DA: Paraffin removal from tissue sections for digestion and PCR analysis. Biotechniques 1999, 26:198-200.

28. Tornesello ML, Buonaguro FM, Meglio A, Buonaguro L, Beth-Giraldo E, Giraldo G: Sequence variations and viral genomic state of human papillomavirus type 16 in penile carcinomas from Ugandan patients. J Gen Virol 1997, 78(Pt 9):2199-2208.

29. Gentile G, Giraldo G, Stabile M, Beth-Giraldo E, Lonardo F, Kyalwazi SK Perone L, Ventruto V: Cytogenetic study of a cell line of human penile cancer. Ann Genet 1987, 30:164-169.

30. Andersson $P$, Kolaric A, Windahl $T$, Kirrander $P$, Soderkvist $P$, Karlsson MG: PIK3CA, HRAS and KRAS gene mutations in human penile cancer. $J$ Urol 2008, 179:2030-2034.
31. Levi JE, Rahal P, Sarkis AS, Villa L: Human papillomavirus DNA and p53 status in penile carcinomas. Int J Cancer 1998, 76:779-783.

32. Soufir N, Queille S, Liboutet M, Thibaudeau O, Bachelier F, Delestaing G, Balloy BC, Breuer J, Janin A, Dubertret L, Vilmer C, Basset-Seguin N: Inactivation of the CDKN2A and the p53 tumour suppressor genes in external genital carcinomas and their precursors. Br J Dermatol 2007, 156:448-453.

33. Poetsch M, Hemmerich M, Kakies C, Kleist B, Wolf E, Vom DF, Hakenberg OW, Protzel C: Alterations in the tumor suppressor gene p16(INK4A) are associated with aggressive behavior of penile carcinomas. Virchows Arch 2011, 458:221-229

34. Rocha RM, Ignacio JA, Jordan J, Carraro DM, Lisboa B, Lopes A, Carvalho KC, Da Cl, Cubilla A, Guimaraes GC, Vassallo J, Soares FA: A clinical, pathologic, and molecular study of $\mathrm{p} 53$ and murine double minute 2 in penile carcinogenesis and its relation to prognosis. Hum Pathol 2012, 43:481-488.

35. Yanagawa N, Osakabe M, Hayashi M, Tamura G, Motoyama T: Detection of HPV-DNA, p53 alterations, and methylation in penile squamous cell carcinoma in Japanese men. Pathol Int 2008, 58:477-482.

doi:10.1186/1750-9378-8-2

Cite this article as: Annunziata et al: Somatic mutations of STK11 gene in human papillomavirus positive and negative penile cancer. Infectious Agents and Cancer 2013 8:2.

\section{Submit your next manuscript to BioMed Central and take full advantage of:}

- Convenient online submission

- Thorough peer review

- No space constraints or color figure charges

- Immediate publication on acceptance

- Inclusion in PubMed, CAS, Scopus and Google Scholar

- Research which is freely available for redistribution

Submit your manuscript at www.biomedcentral.com/submit
C Biomed Central 